\title{
THE PROCESS OF SHRINKAGE AS A CHALLENGE TO URBAN GOVERNANCE
}

\author{
TADeusz Stryjakiewicz, Emilia JaroszeWSKa \\ Institute of Socio-Economic Geography and Spatial Management, \\ Adam Mickiewicz University in Poznań, Poland \\ Manuscript received: March 9, 2016 \\ Revised version: April 26, 2016
}

\begin{abstract}
StryJaKieWicz T., JAROsZEWSKa E., 2016. The process of shrinkage as a challenge to urban governance. Quaestiones Geographicae 35(2), Bogucki Wydawnictwo Naukowe, Poznań, pp. 27-37, 4 figs, 2 tables.

ABSTRACT: For many decades most researchers, planners and local authorities have been focusing almost exclusively on urban growth and its socio-economic and spatial consequences. However, in the current debate concerning the future of cities and regions in Europe the process of their shrinkage starts to attract more attention. In the conditions of a declining population, urban governance is an important challenge for local authorities, being usually much more difficult than during the periods of population growth.

The experience of cities affected by shrinkage shows that there is no simple method of counteracting negative consequences of this process. Regeneration strategies vary a lot, depending mostly on the way the problem is perceived by both central and local governments. The strategies can either choose an adaptive approach (the acceptance of shrinkage and adjustment to it), or attempt to renew growth (shrinkage is treated as just a temporary phenomenon). Quite often the problem is ignored and no action is taken at all.

In the paper the authors discuss the conditions and consequences of different approaches towards the process of shrinkage and present examples of regeneration strategies (together with their assessment). They conclude with recommendations for future urban policies.
\end{abstract}

KEY WORDS: shrinking cities, urban governance, regeneration strategies

Tadeusz Stryjakiewicz, Emilia Jaroszewska, Institute of Socio-Economic Geography and Spatial Management, Adam Mickiewicz University in Poznań, Dzięgielowa 27,61-680 Poznań, Poland; e-mail: tadek@amu.edu.pl, emiliagp@amu.edu.pl

\section{Introduction}

Cities and processes related to them undergo a never-ending transformation which makes the model of city management change too, as reflected by the transition from government to governance (Bailey 1993). Today local governance is understood as a flexible decision-making model based on loose horizontal links among various actors (public and private) (John 2001). The policy conducted in this way rests on the process of learning. It is open to other participants and creates a climate of cooperation in order to achieve common goals. As Musterd and Kovacs put it (2013: 14), "policy makers would be wise to incorporate all available knowledge about pathways and place characteristics, and how to capitalise existing networks". That is why it is so important to gain an insight into the processes that take place in modern cities, and to revise policies pursued so far in order to meet new challenges. Urban shrinkage is one of them. This 
process, already present in some cities (usually old industrial centres) of Western Europe and the United States, after 1990 assumed especially large dimensions in post-communist countries. Thus, there appear new challenges: on the one hand, the need to identify the scale, rate and forms of urban shrinkage and how those features differ spatially, and on the other, to revise the urban policies pursued so far, usually designed to follow a growth paradigm treating cities as "growth machines" (Logan, Molotch 1987). That is why shrinking cities are an object of much academic and practical discussion as well as several international research projects. Among the latter one can find:

1) Shrink Smart - The Governance of Shrinkage within a European Context - a project implemented under the Seventh Framework Programme of the European Union ${ }^{1}$, and

2) CIRES - Cities Regrowing Smaller. Fostering Knowledge on Regeneration Strategies in Shrinking Cities across Europe - a project implemented under Action COST ${ }^{2}$ (TU0803).

This article follows from the latter of the listed projects, enriched by the results of a study conducted under grant no. 737/N-COST/2010/0 obtained from the Ministry of Science and Higher Education.

\section{Conceptualisation of urban shrinkage}

The term 'urban shrinkage' has not been defined precisely yet. The research carried out so far (e.g. Oswalt 2005; Steinführer, Haase 2007; Turok, Mykhnenko 2007; Haase et al. 2008, 2013; Mykhnenko, Turok 2008; Pallagst et al. 2009; Cunningham-Sabot et al. 2010; Fol, CunninghamSabot 2010; Reckien, Martinez-Fernandez 2011; Fol 2012; Bontje, Musterd 2012; Wiechmann, Pallagst 2012; Martinez-Fernandez et al. 2012; Wiechmann, Wolf 2013) allows tracing three chief fields of controversy related to this definition:

a) Does the notion of a 'shrinking city' involve exclusively its depopulation (i.e. a drop in the population number), or must there also be

1 The most essential results of this project were published in Bernt et al. (2012); they can also be found at www.shrinksmart.eu.

2 COST - European Cooperation in Science and Technology. other indicators (e.g. a structural crisis of the economy combined with a high unemployment rate, degradation of the housing stock, a great accumulation of social problems)?

b) Does a drop in the population number within a city's administrative limits owing to its growth in the suburban area (hence to the process of suburbanisation) justify describing this city as 'shrinking'? and

c) How long must the period of a population decline be to justify the talk of a 'shrinking city'? In the light of the above dilemmas, it seems that the notion of a shrinking city is gradable, as shown in Fig. 1. Each type of shrinkage demands different forms of governance.

According to the definition adopted in the CIRES project formulated by the Shrinking Cities International Research Network (SCIRN), "A shrinking city is a densely populated urban area that has on the one hand faced a population loss in large parts of it (for at least 5 years, more than $0.15 \%$ annually), and is on the other hand undergoing economic transformation with some symptoms of a structural crisis". This is the definition that will be used henceforth in this article.

The chief causes of urban shrinkage are demographic changes connected primarily with a negative rate of natural increase, the ageing of society, and migration. The questions still open are the identification and classification of the remaining factors responsible for urban shrinkage, and the choice of socio-economic indices characterising this process (Jessen 2012; Wiechmann, Wolf 2013; Jaroszewska, Stryjakiewicz 2014). The difficulty lies in the uniqueness of each city, its history, political situation, and socio-economic condition. As Wu and Martinez-Fernandez (2009) note, the same factors that underlie the socio-economic development of one city may trigger shrinkage in another.

Urban shrinkage has no single explanatory theory. The multi-aspect nature of this process makes it necessary to resort to many theoretical conceptions in order to get an insight into its mechanisms, pattern and effects.

One of the attempted interpretations relies on Myrdal's (1956, after Hoekveld 2012) cumulative causation theory where population decline - working on a 'vicious circle' principle - is both a cause and a result of urban shrinkage. The appearance of one negative impulse has a snowball 


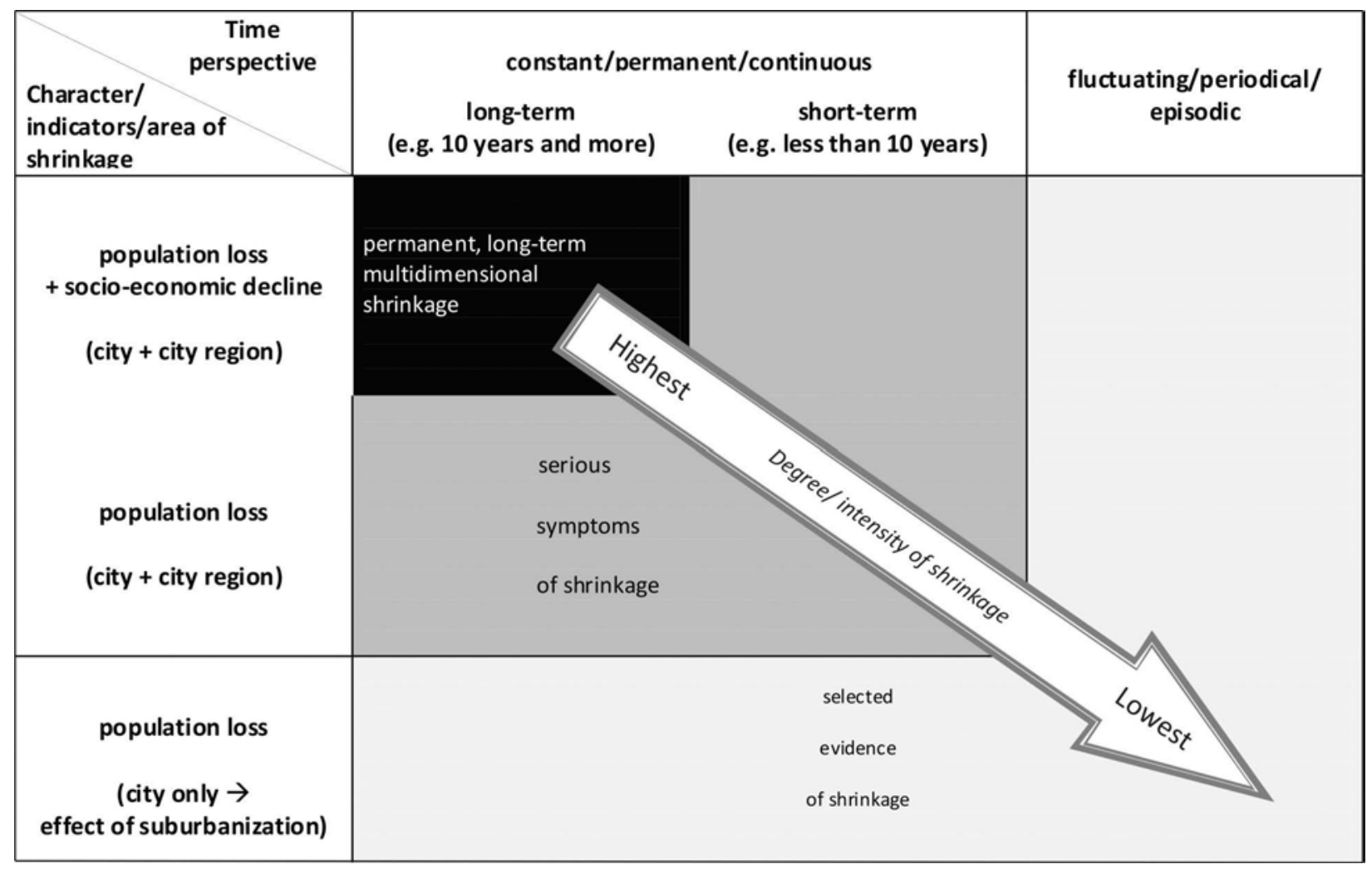

Fig. 1. Typology of shrinking cities - 'graduation' of shrinkage. Source: Stryjakiewicz (2013: 127).

effect, triggering successive undesirable processes and developments. To put it simply, a drop in the population number brought about by the emigration of young people (e.g. as a result of a deepening economic crisis) means a reduction in the number of the population of reproductive age, and the effect is a decrease in births. The disturbance in the age structure of the population of a locality thus created, accompanied by a persistently low total fertility rate and no inflow of new residents, leads to a further intensification of unfavourable demographic changes (in particular, the ageing process). This, in turn, makes the labour force dwindle and affects the local labour market, which generates further adverse effects. Understood in this way, the shrinkage mechanism shows a cumulative tendency and, left to itself, leads over a longer period to the reinforcement of negative consequences in many fields: demographic, economic, social and spatial (Stryjakiewicz et al. 2012). If there appear new external determinants, the process can slow down or accelerate. Theoretically, it is also possible that, stimulated by a new positive impulse, its direction will change.
An answer to the question about the nature of causes making a city or region shrink can also be supplied by a historical analysis. A study of the pattern and direction of evolution of social systems, the institutional context, as well as various events, choices and decisions from the past, can provide a deeper insight into the mechanism of shrinkage of a spatial unit (Bontje, Musterd 2012). This type of explanation relying on the interpretation of historical facts and employing a genetic approach is the essence of the conception known as path dependence (e.g. Arthur 1994; Boschma, Lambooy 1999; David 2000; Mahoney 2000; Gwosdz 2004, 2014). In this approach, shrinkage can be understood as an outcome of a choice made at one time. It is then reinforced, reproduced or transformed by successive chance events. As David (2000) claims, this is a conception combining isolated, unique occurrences with more general growth processes of dynamic structures. Thus, dealing with shrinkage requires a skilful combination of general rules of urban governance with 'tailored' policies oriented to local specificities. 


\section{Urban shrinkage in Europe with a focus on post-socialist cities}

Under the CIRES project, a detailed analysis was made of changes that took place over the years 1990-2010 in the population number of 7,035 European cities with more than 5 thousand inhabitants. The changes taken into consideration were not only those within a city's administrative limits, but also in the administrative units that surround $i^{3}$. In this way cities selected for further analysis were those in which the population decline was not due to suburbanisation. Three types of cities were distinguished: growing (a change in population number of more than $0.15 \%$ annually), stable/stagnating (from 0.15 to $-0.15 \%$ ), and shrinking (under $-0.15 \%$ ). With reference to the group of shrinking cities, the shrinkage process was divided into three types:

a) long-term;

b) short-term; and

c) episodic (cf. Fig. 1).

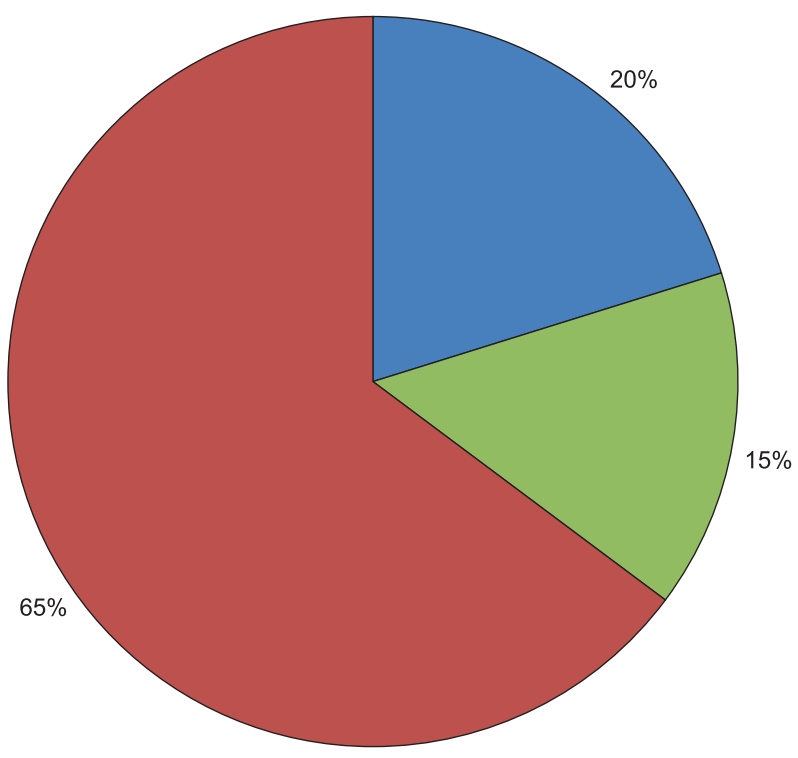

shrinking (<- $-0.15 \%$ per year) $\square$ stable $(-0.15 \%$ to $0.15 \%)$

$\square$ growing (> $0.15 \%$ per year)

Fig. 2. Scale of the process of urban shrinkage in Europe in 1990-2010.

Source: Wiechmann, Wolff (2013: 9); the CIRES project (COST Action - TU0803).

So-called Local Administrative Units (LAU2), in EUROSTAT terminology.
A detailed methodology of the selection of cities for analysis can be found in Wiechmann and Wolff (2013).

The research results (Fig. 2) show 20\% of European cities to be permanently shrinking. However, an analysis of the proportion of the number of shrinking to growing cities in the individual countries is highly illuminating. In those statistics the post-socialist countries of East-Central Europe stand out in a decidedly unfavourable light. The situation is especially grim in Latvia, Romania, Lithuania, Estonia and Bulgaria, where more than $3 / 4$ of their cities are shrinking.

In the light of the above data, there arises a question of the causes of such large-scale urban shrinkage in East-Central Europe. The results of studies conducted so far (e.g. European Commission 2007; Turok, Mykhnenko 2007; Kabisch, Haase 2011; Reckien, Martinez-Fernandez 2011; Haase et al. 2013; Wiechmann, Wolf 2013) suggest that it has been produced by a combination of several factors of a demographic, economic and institutional nature. They include:

a) a decline in the number of births and natural increase;

b) external migrations that intensified especially after the opening of the borders on accession of a large number of those countries to the European Union (in the case of the former GDR - internal migrations, but resulting from the incorporation of this state into the reunified Germany);

c) urban-to-rural migrations (mostly in suburban areas); and

d) the transformation of the economy (in particular its de-industrialisation).

In the case of some states (Bosnia, Estonia, Romania), a motive for migration is often not only economic problems (as in most countries), but also ethnic conflicts. Worth noting is the fact that in the post-socialist Europe all the dimensions of shrinkage, viz. demographic, economic and social, as well as the physical degradation of the urban stock, are closely related, although the process of shrinkage differs in space.

Since the late 1980s, the transformation of the command system into a democratic and market one has proceeded in the individual countries of this part of Europe in a variety of ways and at various rates (e.g. gradualism vs. a 'shock therapy'). 
Also different were, and still are, institutional determinants of this process (e.g. membership of the European Union). Some of the countries under analysis (created after the dissolution of Yugoslavia) were still at war as late as the years 1992-1995.

In all the countries of East-Central and SouthEastern Europe where the socialist system was introduced after the Second World War, the increase in the number of the urban population in the 1950s and '60s was closely connected with forced industrialisation. The service sector started to gain in significance only in the late 1960s (e.g. in Hungary and Serbia) and early 1970s (also in Poland). This made further demographic development of towns possible and boosted the demand for housing. It was usually met by the construction of housing estates out of large-panel prefabricated elements. This meant copying technologies employed in capitalist Western Europe a decade earlier, from which it differed not only in the time lag, but also in the low quality of the buildings constructed. Since the mid-1980s one can observe an intensive suburbanisation process, especially on the margins of capitals and some regional growth centres (like Brno in the Czech Republic, Győr in Hungary, or Cracow and Poznań in Poland), which in itself is another challenge for urban governance.

Almost immediately after 1990 there was also a radical change in the economic structure of towns. The industrial branches that once enjoyed a priority status turned out to be non-competitive after the opening to global processes and the cutting-off of central funding, which in consequence led to their gradual liquidation. An increase in the importance of the service sector (especially trade, finance, legal and administrative services, tourism and recreation) partly compensated for the loss of jobs in the manufacturing sector. Poorly stimulated and supported, in turn, was the development of small, competitive, specialised enterprises (based on endogenous potential $)^{4}$, their clusters, as well as the R\&D sector and the spin-off effects connected with it.

In all the post-socialist countries the pattern of demographic changes was similar, but

\footnotetext{
With a few exceptions, mostly in Poland, where, however, small and medium-sized enterprises did not develop in regions especially affected by the process of shrinkage.
}

often timed differently. What became the greatest problem here was a dramatic decline in the total fertility rate, often termed a 'demographic shock' resulting from the so-called second demographic transition. Earlier, it occurred in wealthier states and, together with migration processes (involving both, out-migration and suburbanisation), has led to a more pronounced socio-economic degradation of many towns in this part of the continent, creating a real challenge for urban governance (Markowski 2013).

\section{Urban policies and attempts to cope with shrinkage}

Urban shrinkage poses a great challenge for administrative and self-government authorities of various levels (from the European Union through the national and regional levels to the local one), as well as for planning institutions. As mentioned earlier, this challenge has assumed a special character in the post-socialist countries of East-Central Europe, where planning culture for years relied on a steady-growth paradigm (cf. Pallagst et al. 2009; Wiechmann 2008; European Parliament 2008; Hollander et al. 2009; OECD 2011; Rumpel, Slach 2012).

On the basis of the results of the Shrink Smart project, Bernt et al. (2012) and Haase (2013) list various kinds of factors determining the nature of a policy adopted towards shrinking cities. They include:

a) the existing governance systems and cultures;

b) political traditions;

c) the way of formulating and addressing problem issues;

d) the nature of multi-level arrangements and relationships;

e) the mode of governance; and

f) the availability and origin of resources.

In the opinion of DiGaetano and Strom (2003), the efficiency of this policy largely depends on the mode of urban governance adopted. They identify five modes: clientelist, corporatist, managerial, pluralist, and populist. Naturally, in reality we often deal with a mixture of those governance forms and the formation of a hybrid mode.

Whatever the existing governance determinants and modes, strategies designed to 
Table 1. Fields of special impact of urban policies in shrinking cities.

\begin{tabular}{|c|c|}
\hline Field of impact & Problems and challenges \\
\hline Socio-demographic structure & $\begin{array}{l}\text { - unfavourable reproductive behaviour and downward demographic ten- } \\
\text { dencies (e.g. low birth rates) } \\
\text { - preventing population outflow, immigration incentives } \\
\text { - population ageing } \\
\text { - dwindling size of households }\end{array}$ \\
\hline Economic structure & $\begin{array}{l}\text { - fighting unemployment and creating new jobs } \\
\text { - attracting investors } \\
\text { - dwindling urban budget receipts and growing budget deficit } \\
\text { - increasing dependence on external funding (in particular from public } \\
\text { means) }\end{array}$ \\
\hline Housing & $\begin{array}{l}\text { - housing vacancies } \\
\text { - deteriorating housing stock } \\
\text { - deteriorating public facilities and spaces }\end{array}$ \\
\hline Physical infrastructure and land use & $\begin{array}{l}\text { - some components of physical infrastructure 'oversized' in the face of falling } \\
\text { demand } \\
\text { - abandoned land as well as infrastructural and post-industrial facilities }\end{array}$ \\
\hline Social infrastructure & $\begin{array}{l}\text { - under-used potential of some child-care and youth facilities (e.g. nurseries, } \\
\text { kindergartens, schools) } \\
\text { - growing demand for facilities and services for older people (e.g. nursing } \\
\text { homes) }\end{array}$ \\
\hline
\end{tabular}

Source: Rink et al. (2009), with the authors' modifications.

overcome the adverse effects of urban shrinkage should accommodate several major controls of this process, which are presented in Table 1.

Strategies intended to respond to the process of shrinkage can be classified in a variety of ways. One of the more interesting and most useful classifications has been proposed by Danielzyk et al. (2002); it is presented in Table 2.

In the CIRES project, this classification was one of the elements on the basis of which three most popular policy approaches were distinguished:

a) counteracting or alleviating the adverse effects of shrinkage;

b) seeking new sources of growth; and

c) promoting positive aspects of shrinkage.
In turn, Stryjakiewicz (2013b) suggests distinguishing two types of strategy using a different criterion:

a) on site (i.e. implemented in the area of a shrinking city), and

b) networking strategies.

The former type primarily embraces measures intended to stimulate local entrepreneurship, reduce unemployment, and revitalise downtown or post-industrial areas. The other involves creating conditions for the intensification of relations with other, more advanced cities, e.g. by improving the quality of transport infrastructure and increasing the frequency of links (which can facilitate commuting to work and school, thus

Table 2. Types of strategies designed to overcome the adverse effects of urban shrinkage.

\begin{tabular}{|l|l|l|l|l|}
\hline \multirow{2}{*}{\multicolumn{1}{|c|}{ Strategies }} & \multicolumn{2}{|c|}{ Active } & \multicolumn{2}{c|}{ Passive } \\
\cline { 2 - 5 } & expansive strategy & maintenance strategy & planning for a decline & $\begin{array}{l}\text { absence of steps acti- } \\
\text { vating a vicious circle } \\
\text { of shrinkage }\end{array}$ \\
\hline Goal & $\begin{array}{l}\text { keeping the popula- } \\
\text { tion within city lim- } \\
\text { its, or even making it } \\
\text { expand }\end{array}$ & $\begin{array}{l}\text { maintaining the at- } \\
\text { tractiveness of exist- } \\
\text { ing urban structures }\end{array}$ & $\begin{array}{l}\text { orderly shrinkage, } \\
\text { qualitative develop- } \\
\text { ment }\end{array}$ & no specified goals \\
\hline $\begin{array}{l}\text { Major forms of urban } \\
\text { policy implementation }\end{array}$ & $\begin{array}{l}\text { development of new } \\
\text { residential areas }\end{array}$ & $\begin{array}{l}\text { development of exist- } \\
\text { ing land-use pattern } \\
\text { and functions, target } \\
\text { group programmes }\end{array}$ & $\begin{array}{l}\text { adation and } \\
\text { reduction of existing } \\
\text { infrastructure, devel- } \\
\text { opment of recreation- } \\
\text { al areas }\end{array}$ & $\begin{array}{l}\text { waiting for external } \\
\text { intral or region (e.g. of } \\
\text { authorities) and for } \\
\text { financial support }\end{array}$ \\
\hline
\end{tabular}

Source: Danielzyk et al. (2002: 25), with the authors' modifications. 
counteracting the outflow of the labour force). Those two strategic orientations in counteracting the adverse effects of shrinkage are presented in Figure 3.

At this point one might agree with Wiechmann's statement (2008: 432) that "we need new scenarios and development programmes that would accommodate the process of urban shrinkage". What is necessary in those measures is the involvement of both, local actors (self-government authorities, enterprises, institutions and organisations of the business environment), as well as supra-local ones (such as ministries of regional development), backed by the European Union programmes and funds. It is essential to liberate urban policy from the obsession of the steadygrowth paradigm, to work out suitable forms of planning ('planning for shrinkage'), and to look at urban shrinkage in terms of chances and possibilities of change that it offers in the development path followed so far ('shrinkage as an opportunity' - cf. Bontje 2004; Hollander et al. 2009).

Whatever the orientation of the urban policy addressing the process of shrinkage, its implementation should follow the pattern worked out by Bernt et al. (2010) under the Shrink Smart project (Fig. 4).

The participants of the Shrink Smart project described examples of good practices, demonstrating that "shrinkage is not an irreversible fate of a city" (Haase 2013: 39). These examples of shrinking cities, now at a stage of re-urbanisation, are Liverpool and Leipzig. Their modern development trajectories are discussed in detail by Rink et al. (2012). In both cities one of the strategies intended to minimise the adverse effects of shrinkage has been a change in their functional structure involving the promotion of so-called cultural industries and the creative sector.

As follows from the report drawn up for the CIRES project (Stryjakiewicz 2013a), in working out urban development policies and strategies in East-Central Europe, social perception of and interest in the process of urban shrinkage are closely connected with the advancement of the institutional transformation in those countries and with the scale (intensity) of the process of shrinkage. In the countries that entered the transformation path earlier and became European Union members earlier (the Czech Republic, Estonia, Poland, Slovakia, Slovenia, Hungary), social debate and measures taken by the authorities seem more advanced than, for example, in the Balkan states (Bosnia and Herzegovina, Bulgaria, Macedonia). Generally, strategies predominant in the countries of East-Central Europe are those intended to overcome (ameliorate) the negative effects of shrinkage ('mitigation strategies'), while those oriented towards development in the conditions of shrinkage are still absent. The 'shrink smart' rule and the skilful adjustment of cities to shrinkage that it involves are still a matter of urban policies of the future in this part of Europe. There should be various groups of beneficiaries involved in their formulation (EU institutions, central governments, local authorities, academic

\section{On site strategies}

\section{Goals:}

reducing unemployment by stimulating entrepreneurship

urban renewal programmes (renewal of downtown parts, protection of industrial heritage, revitalisation of industrial facilities for cultural /educational purposes)

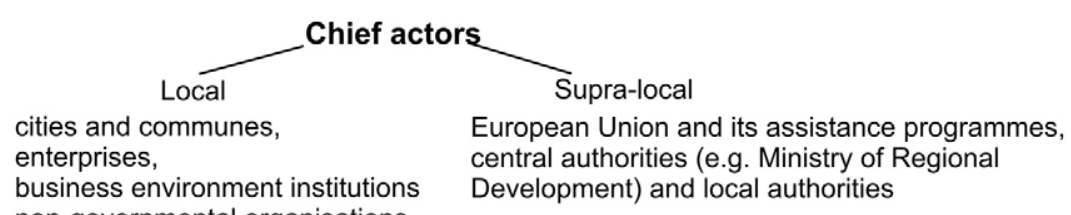

non-governmental organisations
European Union and its assistance programmes, Development) and local authorities

\section{Networking strategies}

based on cooperation with other, more advanced spatial units

Fig. 3. Two strategic orientations intended to counteract the adverse effects of urban shrinkage. Source: own compilation. 


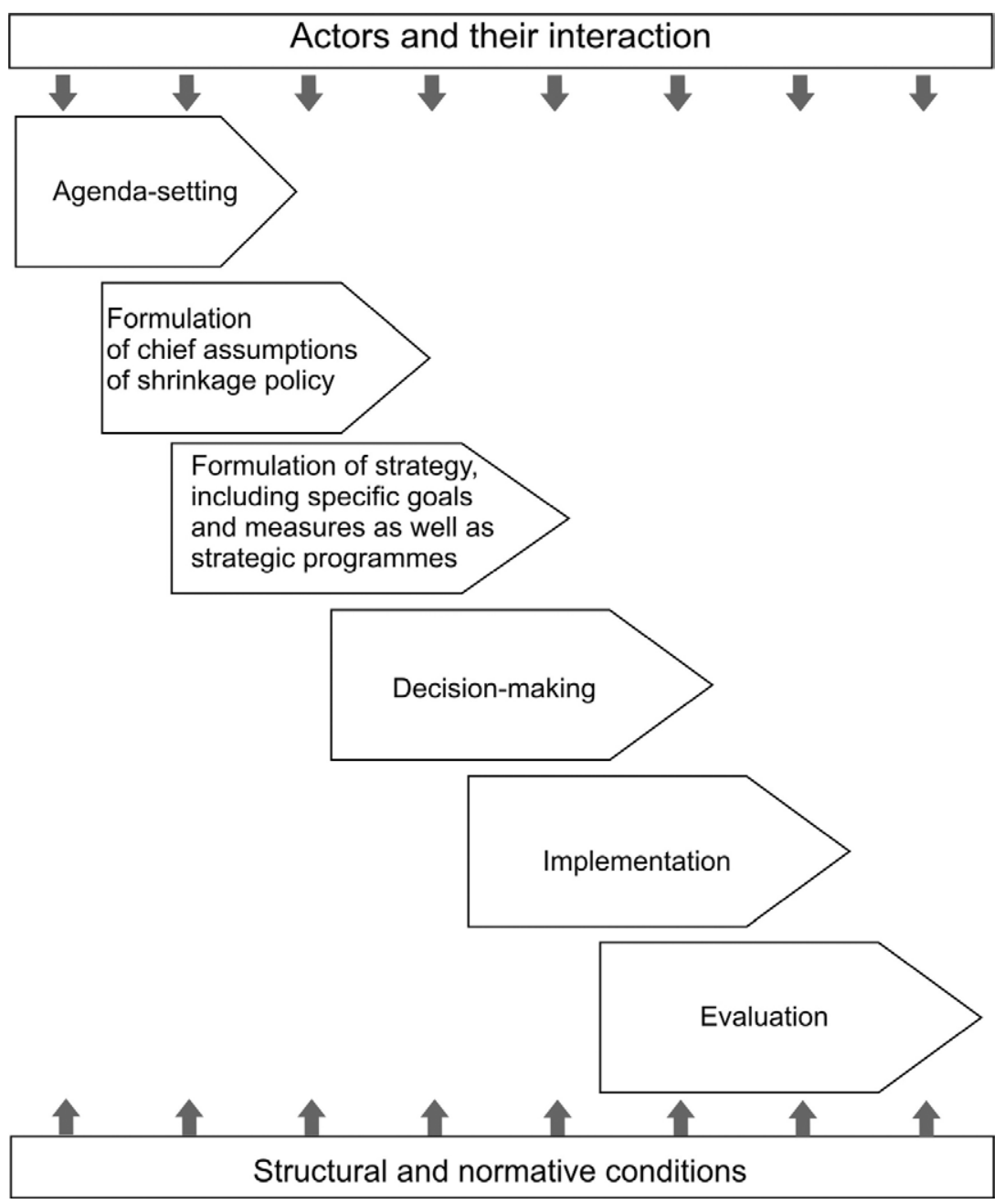

Fig. 4. Stages of urban policy implementation in shrinking cities. Source: Bernt et al. (2010), with the authors' modifications.

circles, business people, non-governmental organisations). A special role in working out policies dealing with shrinkage is played by local authorities.

It is almost certain that local authorities will not be able to cope with the effects of shrinkage of their city on their own. Hence it is necessary to engage all local actors in the task, including enterprises, schools, NGOs and supra-local government institutions (supported by European Union programmes and funds), academic circles, and (or perhaps primarily) local communities. It is the dialogue with residents, their involvement and knowledge of the problems and challenges resulting from the advancing shrinkage of their city that seem to be of key significance for the successful implementation of a right policy. As Hospers (2013, after Lowndes et al. 2006) emphasises, to encourage greater resident involvement the so-called CLEAR approach might be useful:

- Can do (have enough knowledge, skills and resources to participate);

- Like to (act from a "sense of place" and belief in the community);

- are Enabled to (are well-supported by government to participate);

- are Asked to (are approached actively by stakeholders to join in);

- are Responded to (can see that their activities make a difference).

Thus, it will be necessary to build confidence in steps taken by local authorities and make an effort to increase the participation of residents in measures implemented in the city where they live. First, however, urban shrinkage must stop being a taboo in their perception (Wiechmann 2008) and there must be a change in mentality 
(cf. Bernt et al. 2014). As Hospers (2013) states, for a local government growth has usually meant power, hence, while many local leaders are aware of urban shrinkage and adopt policies to cope with its negative effects, for fear of losing voters they often treat it as a "silent process" (Cunningham-Sabot 2008). That is why local governments, planners and political leaders must realise that shrinkage need not automatically imply the fall of their cities. On the contrary, with a suitable policy and resident involvement it may lead to a rise in living standards and the city's qualitative development. One can therefore agree with Panagopoulos and Barreira (2012: 289) that "planners and political leaders must continue to make efforts to understand the characteristics of shrinkage and develop methods to manage this decline in a planned and creative way that will sustain the quality of life of the remaining population".

The awareness of the process of urban shrinkage and its consequences is still low (in particular in post-socialist countries), but this has started to change. Especially in the last few years one can observe that the discussion about challenges posed by urban shrinkage slowly becomes part of public debate (Zarzadzanie..., 2013). One can also identify measures - taken mostly at the regional level - intended to cope with the negative effects of this process. Taking Poland as an example, in Opole voivodeship, in which Jaroszewska and Stryjakiewicz (2014) found that as many as $78 \%$ of towns have been shrinking, a Special Demographic Zone has been set up. Among its most urgent tasks are halting the outflow of young people by creating attractive jobs as well as greater assistance to young families (e.g. nursery-kindergarten care for children) and to senior citizens (Sebesta 2013). Another example of a growing awareness of local decision-makers concerning the unfavourable demographic processes is the Plan to counteract depopulation in Eódź voivodeship. Family, Children, Work, designed in 2013 (Łódź voivodeship, and in particular its capital, the city of Łódź, are units especially heavily hit by the shrinking process).

So far, the above examples have been isolated cases. Still missing are comprehensive regeneration strategies that would integrate the 'hardware' (housing, infrastructure), 'software' (image, governance) and 'human resources' (social and economic structures) types of intervention (Wiechmann 2013). An important challenge will also be making residents themselves more involved in the life of their cities, and in particular in the working out of a common vision of their development and transformation in the conditions of shrinkage.

\section{Challenges for the future}

There is no doubt that urban shrinkage will be a major challenge for future urban policies, especially in post-socialist cities. Hence a discussion about a strategy counteracting the detrimental effects of this process seems to be highly topical. Of key importance for the future of many shrinking cities will be the creation of visions of their longterm development in the conditions of shrinkage. The visions should accommodate the fact that shrinking cities are also units that age faster than the remaining ones in demographic terms. This will additionally make it necessary for them to adapt not only to the conditions of a dwindling population, but also to the advancing process of population ageing. An important, so far poorly articulated, element of the discussions about shrinkage should be migration policy.

\section{References}

Arthur B., 1994. Increasing returns and path dependence in the economy. University of Michigan Press, Ann Arbor.

Bailey S., 1993. Public choice theory and the reform of local government in Britain: From Government to Governance. Public Policy and Administration 8(2): 7-24.

Bernt M., Cocks M., Couch C., Grossmann K., Haase A., Rink D., 2012. Shrink smart. Policy response, governance and future directions. Research Brief 2, Helmholtz Centre for Environmntal Research - UFZ, Leipzig.

Bernt M., Coach C., Haase A., Cocks M., Grossman K., Cortese C., Krzysztofik R., 2014. Why and how does(n't) urban shrinkage get onto the agenda? Experiences from Leipzig, Liverpool, Genoa and Bytom. International Journal of Urban and Regional Research 38(5): 1749-1766.

Bontje M., 2004. Facing the challenge of shrinking cities in East Germany: The case of Leipzig. GeoJournal 61(1): 13-21.

Bontje M., Musterd S., 2012. Understanding shrinkage in European regions. Built Environment 38(2): 153-161.

Boschma R.A., Lambooy J.G., 1999. Evolutionary economics and economic geography. Journal of Evolutionary Economics 9: 411-429.

Cunningham-Sabot E., Jaroszewska E., Fol S., Roth S., Stryjakiewicz T., Wiechmann T., 2010. Processes de decroissance urbaine. In: Baron M., Cunningham-Sabot E., 
Grasland C., Riviere D., Van Hamme G. (eds), Ville et regions europeennes en decroissance. Lavoisier, Paris.

Danielzyk R., Mielke B., Zimmer-Hegmann R., 2002. ILS Beiratsbericht Demographische Entwicklung - Schrumpfende Stadt. Institut für Landes- und Stadtentwicklungsforschung des Landes Nordrhein-Westfalen, Dortmund.

David P. A., 2000. Path dependence, its critics and the quest for 'Historical Economics'. In: Garrouste P., Ioannides S. (eds), Evolution and Path Dependence in Economic Ideas: Past and Present. Elgar, Cheltenham.

Di Gaetano A., Strom E., 2003. Comparative urban governance. An integrated approach. Urban Affair Review 38(3): 356-395.

European Parliament, 2008. Shrinking regions: A paradigm shift in demography and territorial development. Online: http://www.europarl.europa.eu/ meetdocs/ 2004_2009/documents/dv/pe408928_/pe408928_ en.pdf. (accessed 20 April 2011).

Fol S., 2012. Urban shrinkage and socio-spatial disparities: Are the remedies worse than the disease? Built Environment 38(2): 259-275.

Fol S., Cunningham-Sabot E., 2010. ‘Déclinurbain' et shrinking cities: une évaluation critique des approches de la décroissance urbaine. Annales de géographie 4(674): 359-383.

Gwosdz K., 2004. Ewolucja rangi miejscowości w konurbacji przemystowej. Przypadek Górnego Ślaska (1830-2000) (Evolution of the rank of a locality in an industrial conurbation. The case of Upper Silesia). Instytut Geografii i Gospodarki Przestrzennej Uniwersytetu Jagiellońskiego, Kraków.

Gwosdz K., 2014. Pomiędzy stara a nowa ścieżka rozwojowa. Mechanizmy ewolucji struktury gospodarczej i przestrzennej regionu tradycyjnego przemystu na przykładzie konurbacji katowickiej po 1989 roku (Between the old and the new path of development). Instytut Geografii i Gospodarki Przestrzennej Uniwersytetu Jagiellońskiego, Kraków.

Haase A., 2008. Reurbanisation - an analysis of the interaction between urban and demographic changes as a comparison between European cities. Die Erde 139(4): 309-332.

Haase A., 2013. No one-size-fits-all. O różnorodności kurczących się miast w Europie (No one-size-fits-all. On the diversity of shrinking cities in Europe). In: Zarzadzanie rozwojem miast o zmniejszajacej się liczbie ludności (w kontekście perspektywy finansowej 2014-2020). Kancelaria Senatu Rzeczypospolitej Polskiej, Warszawa.

Haase A., Bernt M., Großmann K., Mykhnenko V., Rink D., 2013. Varieties of shrinkage in European cities. European Urban and Regional Studies 12: 1-17.

Hollander J. B., Pallagst K., Schwarz T., Popper F., 2009. Planning shrinking cities. Progress in Planning (special issue: Emerging Research Areas) 72(4): 223-232.

Hospers G.J., 2014. Urban shrinkage in the EU. In: Richardson H.W., Nam C.W. (eds), Shrinking Cities: A Global Perspective. Routledge, Abingdon.

Jaroszewska E., Stryjakiewicz T., 2014. Kurczenie się miast w Polsce (Shrinking cities in Poland). In: Stryjakiewicz T. (ed.), Kurczenie się miast w Europie Środkowo-Wschodniej. Bogucki Wydawnictwo Naukowe, Poznań.

Jessen J., 2012. Conceptualizing shrinking cities - a challenge for planning theory. In: Ganser R., Piro R. (eds), Parallel patterns of shrinking cities and urban growth. Spatial planning for sustainable development of city regions and rural areas. Ashgate, Farnham, Surrey.
John P., 2001. Local governance in Western Europe. Sage, London.

Kabisch N., Haase D., 2011. Diversifying European agglomerations: Evidence of urban population trends for the 21st century. Population, Space and Place 17: 236-253.

Logan, J., Molotch, H., 1987. Urban fortune: The political economy of place. University of California Press, Berkeley.

Lowndes V., Pratchett L., Stoker G., 2006. Diagnosing and remedying the failings of official participation schemes: The CLEAR framework. Social Policy and Society 5: 281291.

Mahoney J., 2000. Path Dependence in Historical Sociology. Theory and Society 29: 507-548.

Markowski T., 2013. Wykład wprowadzający (Introductory lecture). In: Zarzadzanie rozwojem miast o zmniejszającej się liczbie mieszkańców (w kontekście perspektywy finansowej 2014-2020). Kancelaria Senatu RP, Warszawa.

Martinez-Fernandez C., Wu C-T., Schatz L.K., Taira N., Vargas-Hernández J.G., 2012. The shrinking mining city: Urban dynamics and contested territory. International Journal of Urban and Regional Research 36(2): 245-260.

Musterd S., Kovács Z. (eds), 2013. Place-making and policies for competitive cities. Wiley-Blackwell. Oxford.

Myrdal G., 1957. Economic theory and underdeveloped regions. Duckworth, London.

OECD, 2011. Przeglady Krajowej Polityki Miejskiej: Polska (Overviews of National Urban Policies: Poland).

Oswalt P., 2006. Shrinking cities. Vol. 1: Ostfildern: international research. In: Oswalt P., Rieniets T., Atlas of shrinking cities. Hatje-Canz Verlag, Ostfildern-Ruit.

Oswalt P., Rieniets T. (eds), 2006. Atlas of shrinking cities. Hatje-Canz Verlag: Ostfildern-Ruit.

Pallagst K. et al. (eds), 2009. The future of shrinking cities: Problems, patterns and strategies of urban transformation in a global context. Center for Global Metropolitan Studies, UC Berkeley, Monograph Series.

Panagopoulos T., Barreira A.P., 2012. Shrinkage perceptions and smart growth strategies for the municipalities of Portugal. Built Environment 38(2): 276-292.

Reckien D., Martinez-Fernandez C., 2011. Why do cities shrink? European Planning Studies 9(8): 1,375-1,397.

Rink D., Haase A., Bernt M. et al., 2009. Specification of working model, Work Package 1, Shrink Smart Project. Online: http:// www.ufz.de/ export/ data/ 400/ 39013_WP1_Paper_D1_D3_FINAL300909.pdf (accessed 15 January 2014).

Rumpel P., Slach O., 2012. Governance of shrinkage of the city of Ostrava. European Science and Art Publishing, Prague.

Sebesta J., 2013. Zapobieganie i przeciwdziałanie procesom depopulacji jako wyzwanie horyzontalne województwa opolskiego (Prevention of and counter-measures to depopulation processes as a horizontal challenge to Opole voivodeship). In: Zarzadzanie rozwojem miast o zmniejszającej się liczbie mieszkańców (w kontekście perspektywy finansowej 2014-2020). Kancelaria Senatu RP. Warszawa.

Steinführer A., Haase A., 2007. Demographic change as future challenge for cities in East Central Europe. Geographiska Annaler B 89(2): 183-195.

Stryjakiewicz T., 2013a. The process of urban shrinkage and its consequences. Romanian Journal of Regional Science, Special Issue New Urban World (7): 29-40.

Stryjakiewicz T., 2013b. Proces kurczenia się miast (urban shrinkage) i jego konsekwencje (Urban shrinkage and its consequences). In: Gaczek W.M. (ed.), Dynamika, cele i polityka zintegrowanego rozwoju regionów. Aspekty teore- 
tyczne i zarzadzanie w przestrzeni. Bogucki Wydawnictwo Naukowe, Poznań: 125-134.

Stryjakiewicz T., Ciesiółka P., Jaroszewska E., 2012. Urban shrinkage and the post-socialist transformation: The case of Poland. Built Environment 38(2): 197-213.

Turok I., Mykhnenko V., 2007. The trajectories of European cities, 1960-2005. The International Journal of Urban Policy and Planning 24(3): 165-182.

Turok I., Mykhnenko V., 2008. East European Cities: Patterns of growth and decline, 1960-2005. International Planning Studies 13(4): 311-342.

Wiechmann T., 2008. Conversion strategies under uncertainty in post-socialist shrinking cities: The example of Dresden in Eastern Germany. In: Pallagst K., et al. (eds), The future of shrinking cities: Problems, patterns and strategies of urban transformation in a global context. IURD, Berkeley.

Wiechmann T., 2013. Shrinking cities in Europe: Evidence from the COST Action Cities Regrowing Smaller (CIRES). Final Conference of the EU COST Action Cities Regrowing Smaller (CIRES), 12-13 Sept. 2013. Essen.
Wiechmann T., Pallagst K., 2012. Urban shrinkage in Germany and the USA: A comparison of transformation patterns and local strategies. International Journal of Urban and Regional Research 36(2): 261-280.

Wiechmann T., Wolff M., 2013. Urban shrinkage in a spatial perspective: Operationalization of shrinking cities in Europe, 1990-2010. AESOP-ACSP Joint Congress, 15-19 July 2013, Dublin.

Wu T., Martinez-Fernandez C., 2009. Shrinking cities: A global overview and concerns about Australian cases. In: Pallagst K. et al. (eds), The future of shrinking cities: Problems, patterns and strategies of urban transformation in a global context. IURD, Berkeley.

Zarządzanie rozwojem miast o zmniejszającej się liczbie mieszkańców (w kontekście perspektywy finansowej 2014-2020) (Management of the development of cities with declining populations in the context of the financial perspective 2014-2020), 2013. Kancelaria Senatu RP, Warszawa. 